\title{
INVESTING INTO MICROFINANCE
}

\author{
Karel Janda ${ }^{1}$, Barbora Svárovská ${ }^{2}$ \\ ${ }^{1}$ University of Economics, Prague, W. Churchill Square 4, \\ Prague 3, 13067, Czech Republic, \\ ${ }^{2}$ Charles University, Opletalova 26, Prague 1, 110 00, Czech Republic, \\ E-mails: ${ }^{1}$ Karel-Janda@seznam.cz (corresponding author); ${ }^{2}$ bsvarovska@gmail.com
}

Received 20 October 2009; accepted 27 May 2010

\begin{abstract}
This paper investigates investment performance of microfinance investment funds. The examined funds have recorded lower total risk than global stocks and bonds (measured by four benchmark indices) with moderate but stable returns. The analysis revealed that investment in microfinance investment funds that focus especially on debt instruments represents an attractive opportunity for the portfolio diversification as this asset class does not show any positive correlation with global or emerging capital markets. At the same time, it provides adequate risk-adjusted returns and may be therefore attractive not only for investors with a particular interest in the socially responsible aspect of investment into microfinance.
\end{abstract}

Keywords: microfinance, investment, funds, risk, return, regression.

Reference to this paper should be made as follows: Janda, K.; Svárovská, B. 2010. Investing into microfinance, Journal of Business Economics and Management 11(3): 483-510.

\section{Introduction}

This paper presents an original case study of selected microfinance investment funds. We compare their risk/return characteristics against given world and emerging markets equity and fixed income indices. We reach an affirmative answer to the question whether microfinance (i.e. studied microfinance investment funds) can be attractive opportunity from the portfolio diversification point of view.

The steady development of microfinance institutions (MFIs) is a characteristic feature of many developing and some emerging market economies, especially in Asia, South America, Africa and in some post-communist European countries. While the origins of microfinance are very much connected with self-help groups or donor support schemes (Bauer et al. 2008), the modern microfinance becomes more and more integrated into standard capital markets (Armendáriz de Aghion and Morduch 2005). Nowadays, about half of the funds flowing into microfinance sector from developed countries is channeled to MFIs through specialized financial intermediaries that are collectively referred to as microfinance investment vehicles (MIVs) (Forster and Reille 2008), which propose a collective investment in a wide and diversified spectrum of microfinance institutions.

To allow investors to choose the right microfinance investment opportunity accord- 
ing to own preferences (performance, risk and social impact characteristics) and make comparisons among them as it is common when deciding for a standard bond or equity investment, there is, according to a wider microfinance investment community, a need for both deeper evaluation and rating of microfinance investment funds and microfinance institutions themselves ${ }^{1}$. More new private and institutional investor oriented funds enlarging the pool of current microfinance investment instruments would likewise support the flow of funds.

Given the existing results presented in the next section, the contribution of our case study is to analyze risk characteristics and performance of selected microfinance investment funds against given equity and fixed income indices over a defined study period as opposed to direct analysis of MFI, which was done previously. The advantage of evaluating directly microfinance investment funds is that we shall base our study on their monthly net asset values and therefore we may use much more recent and more frequent data than it was the case of studies mentioned in the previous paragraphs, which used annual data based on MFIs' annual financial reports. By doing so, we may already examine some first impacts of the recent turmoils on financial markets.

To asses the strength (in terms of both the risky nature of investment and returns offered) of the microfinance investment funds sector we shall (similarly to the work by Galema et al. 2008) refer their attributes to global stock and fixed income markets (represented by the Morgan Stanley Capital International World Index and the Markit iBoxx USD Overall Index respectively) as well as to alternative emerging market asset classes (MSCI Emerging Markets Diversified Financials Index and the J. P. Morgan Emerging Market Bond Index Plus). Precisely, we shall ask in the first time whether microfinance investment funds show any significant correlation with global developed markets as well as emerging markets. If this is not the case we could argue that microfinance funds represent a valuable portfolio diversification opportunity.

Our assumption that underlying assets of microfinance investment funds, i.e. loans to microfinance institutions or equity participations in such institutions, are not (or only marginally) exposed to global markets is backed by two special features of microfinance. We will briefly discuss these two features in the following paragraphs.

Firstly, microfinance institutions implement special risk management techniques uncommon for developed credit markets in order to ensure smooth repayment of loans provided. These features include the provision of short-term and small-size loans with high frequency of installments and flexible repayment schedules, the use of dynamic incentives by conditioning a new loan on full repayment of a previous one, the group-lending mechanism and focus on women customers as well as knowledgeable staff understanding rural and low income customers that instantly remain in touch with their clients and know their financial capacities. Therefore, despite the fact that microloans are provided without the collateral requirement the delinquency figures remain very low.

${ }^{1}$ Rating of microfinance institutions has, nevertheless, progressed immensely over the last years. See for example O'Donohue et al. (2009). 
However, there are also powerful reasons why some features of microcredit could induce the participants to take more risk. For example, group liability component may induce all members not to repay in a situation when one group member is in trouble. This could be particularly relevant if worsening economic conditions hit some members and as a consequence there could be a higher risk of contagion to other members compared to standard individual-level lending. Similar argument could be made about other characteristics. The point is that apriori it is not clear that microcredit borrowing (and hence the funds as well) has to be less risky. An interesting experimental evidence on the relation between microcredit and risk taking is provided by Giné et al. (2006) and by Cassar and Wydick (2008).

Secondly, microfinance customers are in general small entrepreneurs who provide essential services and products to a closer community and operate in the informal economy. Their exposure to the formal domestic economy as well as international markets is therefore limited and should not have impact on their repayment behavior. This feature of microfinance suggests low sensitivity of microfinance to global economic shocks like the recent financial crisis.

Second hypothesis, which we are going to examine, is a question whether the performance of studied microfinance funds surpasses returns generated by the above mentioned indices or whether they record at least comparable returns. Shall the two previously stated hypotheses be confirmed, we may see the microfinance sector as a class of assets that is able to compete for the attention of both socially responsible investors as well as commercially oriented institutional asset managers. In consequence, this move could bring more funding to the sector (and deeper down the sector), which would surely be a positive sign for developing and emerging market countries.

The structure of this article is the following. After this short introduction, we provide a short characterization of microfinance followed with an overview of related studies. Then we characterize the microfinance investment funds covered in this article. The analytical results are presented in the next section, which is the main section of the whole article. The last section Conclusions provides an overview of the results and some ideas about the future extensions of this article.

\section{The Characterization of Microfinance}

Microfinance is foremost known for providing microloans to small entrepreneurs in developing countries who lack the access to credit from formal financial institutions. The provision of microloans is characterized by small amounts that are lent, group lending mechanism, regular repayment schedules and the short-term nature of loans. High administrative cost of this kind of banking are compensated for by rather high annual rates of interest. MFIs' interest rates can range from 18 to 60 percent, depending on the conditions in each MFI's service area (Grameen Foundation: http://www. grameenfoundation.org).

Access to credit, however, can be critical as microfinance institutions' customers are in 
vast majority the poorest or low-income microentrepreneurs ${ }^{2}$ who would not otherwise be served by commercial banks because they are considered high risks due to the lack of collateral and/or credit history. They seek credit in order to set up or manage their own business that may range from making handcrafts, tortilla-making business to running small neighborhood shops.

In addition, according to Bauer et al. (2008), the structure of microcredit loan contracts helps to accumulate capital to people with self-discipline problems who lack suitable saving devices that foster regular deposits and that limit withdrawals. Even though the credit provided is not meant to cover daily financial needs of poor households (from developed markets' point of view microloan is an investment loan instead of a consumer loan), poor households running their own business often do not distinguish much in this respect. According to Cull et al. (2008) microloans are especially important with respect to their ability to expand households' abilities to cope with emergencies, manage cash flows, and invest for the future - basic financial capabilities that most of us take for granted but that are especially critical for low-income households operating on tight margins.

Microfinance is not a panacea for a wide-scale poverty eradication, but it is perceived as a tool for economic development and aiding the poor. Its uniqueness could be found in its role in the promotion of self-employment as well as gender empowerment (as the main focus of microfinance institutions is on women customers). Cull et al. (2008) see microfinance as a vision of poverty reduction that centers on self-help rather than direct income redistribution. We could argue to what extent the microfinance programs have been successful in their mission of poverty elimination (many case studies and research projects have profoundly addressed this issue), nevertheless all agree that the microfinance itself, and only the microfinance is not a general instrument how to reach economic growth on a national level and poverty reduction.

The microfinance movement has evolved since 1970s when first MFIs were set up and today's microfinance involves also other services beyond microcredit such as microsavings, insurance, remittances as well as training and advisory programs.

The economic theory and the principle of diminishing marginal returns to capital derived from the assumption of the concavity of the production function suggest that lowincome entrepreneurs should earn higher returns on additional capital than it is the case for rich entrepreneurs that have already made some investments. It suggests that poor people would be able to pay higher interest rates on their loans, which would result in higher returns for financial providers. And yet commercial banks do not turn their focus from the more rich clients towards small badly-off entrepreneurs.

The formal financial sector fails to provide credit to low-income clients despite diminishing marginal returns of capital firstly due to the nature of the target group and the associated high degree of risk and secondly due to the nature of the demand (i.e. poor

${ }^{2}$ Cull et al. (2008) distinguish between the poorest and low-income customers that are poor but substantially better off than the poorest. 
clients wish to borrow rather small amounts in order to be able to safely repay while as their get better off they may wish to borrow more to expand they business further). We shall underline the major obstacles that discourage local commercial banks from poor clients.

Financial markets in general (also in developed economies) are imperfect and are not in line with the assumption of the economic theory of perfect and costless information and suffer from the presence of the asymmetry of information that may lead to problems of adverse selection and moral hazard.

With respect to the adverse selection problem we consider lending institutions that always consider the profit they earn on loans and their riskiness. Nevertheless, they lack necessary information about the nature of borrowers and their projects (in developing countries credit institutions do not dispose neither of the credit history of a borrower or a statement of income they could rely on).

Therefore, they are not able to distinguish between safe and risky costumers. Lending institutions would therefore like to charge higher interest rates in order to compensate for possible losses from unpaid loans. By doing so, however, they discourage safe clients while risky borrowers will be willing to pay higher rates of interest. The interest rate charged therefore may itself affect the riskiness of loans.

Secondly, agency problems due to the asymmetry of information and the risk of moral hazard are present between clients and the lending institution (principal), which does not have reliable information neither about the credit quality of a borrower when the microloan is accorded, nor about the effort he/she exercises so that his/her business is successful. The ex post moral hazard is associated with the inability of the lender to monitor borrower's real profits in case he demands for a postponement of payments or is directly reluctant to repay. The enforcement of loan reimbursement could be even more troublesome taking into account weak legal institutions that may prevail.

Both adverse selection and moral hazard could be solved if borrowers could credibly offer collateral to secure their loans (Armendáriz de Aghion and Morduch 2005), which is however not possible for many microbusinesses that do not have many assets. The effort of acquiring necessary information in order to decide to who the credit should be accorded could be extremely costly and when we take into account the nature of loans involved in microfinance (in sense of the small size of loans) we see that it is not efficient to undertake such a research as high administrative costs are involved per dollar earned on interests. Additional transaction costs are due to the geographic distribution of clients living in rural areas, which makes the administration of loans difficult and economies of scale hardly possible.

\section{Related Studies}

Our paper is a part of a very recent literature dealing with evaluation of MFIs as an investment opportunity. Gonzalez (2007) conducted an empirical study on MFIs' asset quality as a proxy for the risk of MFIs' portfolios. His study focuses on MFIs' resilience against national macroeconomic shocks measured by changes in GNI (gross 
national income) per capita. His data set consists of data on four portfolio risk indicators (portfolio-at-risk over 30 days and over 90 days, loan-loss rate, and the write-off ratio) of 639 MFIs in 88 countries mainly for the period 1999-2005.

The analysis of Gonzalez shows a statistically significant correlation of changes in GNI only with respect to the portfolio-at-risk over 30 days indicator while for the remaining three any significant impact of domestic macroeconomic events on portfolio quality has not been proved. A strong resilience of microfinance institutions to domestic economy conditions has not, however, been confirmed by a recent study by Krauss and Walter (2008).

Krauss and Walter (2008) examine the correlation of microfinance institutions' performance to international as well as to respective local markets with an objective to find out whether an addition of microfinance assets to portfolio represents an attractive opportunity for an investor seeking portfolio diversification. On the set of annual data of 325 leading MFIs covering the period 1998-2006 Krauss and Walter analyzed the absolute market risk of the microfinance sector by regressing MFIs' key performance parameters (return on equity and profit margin used as profitability indicators, change in total assets and in gross loan portfolio indicating changes in the value of assets, and loan portfolio at risk indicator representing the loan portfolio quality) against S\&P 500, Morgan Stanley Capital International (MSCI) World and MSCI Emerging Markets equity indexes as proxies for global market risk, and against country's GDP as a domestic market risk proxy. In addition, they proposed a way how to derive a relative market risk of investment in microfinance, i.e. within the emerging market investment opportunities, when exploring the relationship of the key MFIs' performance indicators to parameters of the same volume of emerging market commercial banks and businesses in general.

In terms of absolute market risk interconnection, they found that MFIs are not correlated with global capital markets while for the domestic economy correlation they found some significant results. In relative terms compared to benchmark institutions, MFIs were significantly less correlated to global market risk than other examined emerging market financial institutions and businesses. Krauss and Walter concluded, that "MFIs may have useful diversification value for international portfolio investors able to diversify away from country risk exposures. For emerging market domestic investors, who may have this ability to a much more limited extent, domestic microfinance investments do not seem to provide significant portfolio diversification advantages" (Krauss and Walter 2008).

Recent work of Galema et al. (2008) investigates whether adding microfinance funds to a portfolio of risky international assets (equity and bond investment) is beneficial and yields diversification gains. The analysis is based on the mean-variance spanning test that relies on the assumption that investment decisions of investors are solely made on the basis of the mean-variance properties of assets. As a proxy for MFI market returns they use annual returns on equity (ROE) and returns on assets (ROA) of MFI's that report their figures to the MIX Market database ${ }^{3}$. MFI's returns covering the period

3 Microfinance Information Exchange (MIX) is a non profit organization that seeks to gather and provide objective data and analysis on microfinance providers worldwide. It administrates a webbased microfinance information platform the MIX Market (http://www.mixmarket.org). 
from 1997 to 2007 are analyzed against the MSCI World and MSCI Emerging Markets equity indexes as in case of Krauss and Walter (2008) while JP Morgan Global Broad and JP Morgan Emerging Markets Global Composite indexes were used as benchmarks for the fixed income market.

The analysis of Galema et al. (2008) suggests that, in general, microfinance may be attractive for investors seeking a better risk-return profile and more specifically that microfinance investment may be valuable as an addition to the debt part of a globally diversified portfolio. In addition, MFIs' were examined also from the regional point of view where investment in MFIs from Latin America yields the most efficient portfolios.

Microfinance as an investment opportunity is also discussed by Cull et al. (2008), de Sousa-Shields and Frankiewicz (2004), Dieckmann (2007), Forster and Reille (2008), Goodman (2004), Ivatury and Abrams (2005), Ivatury and Reille (2004), Meehan (2004), and Reille and Sananikone (2007).

\section{Characteristics of Studied Microfinance Investment Funds}

In order to find out more about the attractiveness of microfinance and microfinance investment vehicles (MIVs) for investors we have conducted a case study of selected microfinance investment funds. Our study consists of eleven microfinance investment funds (and/or their sub-funds, which differ in currency or investment class, nevertheless may have developed in a similar way over the study period) whose performance data are publicly available and are updated on a monthly basis. From the pool of existing MIVs it concerns, therefore, the most developed funds with transparent portfolio structure inherent to developed financial markets and with clearly defined financial as well as social objectives.

Despite the fact that microfinance investment opportunities are rapidly growing, microfinance funds (MIVs in general) as an investment asset are rather recent. There have been several investment funds whose performance figures were available, thought they could not be included in the survey ${ }^{4}$ as they have launched their activity only last year or in 2007 and the time series were too short to give any tangible results. There were other funds that were excluded from the survey because funds' part of total assets dedicated to investment in microfinance was very small, e.g. 10\% in case of excluded AXA World Funds Development Debt, and therefore the performance of such a fund could not be taken as representative of truly microfinance funds that place much greater part of assets in microfinance. On the other hand, the microfinance investment vehicles universe comprises $91 \mathrm{MIVs}$ of different investment structures worldwide (as of December $31^{\text {st }}$ 2007). Therefore our studied sample, which consist of microfinance investment funds (in

\footnotetext{
${ }^{4}$ Bloomberg Financial Service provides data on several other microfinance investment funds, e.g. Wallberg Global Microfinance Fund (Luxembourg) and EMF Microfinance Fund AGmvK (an openend investment fund incorporated in Liechtenstein) that both launched their activity in October 2008, Developing World Markets Microfinance Fund (June 2008) and Netherlands-based SNS Institutional Microfinance Fund (May 2007), which were eliminated from the study because of their short history.
} 
the form of a mutual fund), is not representative of all MIVs, nor all MIVs of the same investment structure, nevertheless in all cases it concerns funds that private and rather commercially oriented investors not familiar with the microfinance field may consider.

Data examined are monthly Net Asset Values per share (NAVs) ${ }^{\mathbf{5}}$ for each fund and subfund starting from January $31^{\text {st }} 2006$ and continuing up until March $31^{\text {st }} 2009$ that were obtained from the Bloomberg Financial Services. The study period had to be shortened in order to be able to include as many funds as possible. Additional information on fund's investment strategy and objectives, the volume of assets or the geographical allocation of the investment portfolio were acquired from their respective monthly and/or annual reports and from a web-based microfinance information platform the MIX Market.

Microfinance investment vehicles that are subject of this study would fall within a group of commercial MIVs that focus mainly on financial objectives while their social and development contribution is a sort of value added that set these funds apart of traditional mutual funds. Our study included the following five MIV, where three of them have three sub-funds in different currencies each. Therefore in total we considered eleven separate funds.

The first one is the responsAbility Global Microfinance Fund which is a Luxembourgbased open-end fund that was launched on November $25^{\text {th }} 2003$. Its assets are managed by the Credit Suisse Microfinance Fund Management Company. Fund's currency is primarily USD, but its Euro and Swiss Franc classes were also included. The second microfinance-focused fund considered in our study is the responsAbility Microfinance Leaders Fund organized by the responsAbility Social Investments Ltd. and unlike the responsAbility Global Microfinance Fund it is aimed exclusively at institutional investors. The third considered fund is Dual Return - Vision Microfinance Fund. This fund has USD, EUR and CHF investment classes. The fourth considered fund is the Dexia Micro Credit Fund that similarly has three currency sub-funds in American dollar, Euro and Swiss Franc. Last fund covered in our study is Edmond de Rothschild - Saint Honore Microfinance.

Table 1 gives an overview of all eleven microfinance investment funds or sub-funds showing the currency of a fund, fund's legal status, MIV's portfolio structure and assets under management as well as total volume of fund's assets allocated solely in microfinance.

Figure 1 studies the relationship of total assets under management of sample funds and funds' microfinance assets in portfolios as some MIVs are involved in other socially responsible investment opportunities such as the free trade. In the study we took into account only funds that hold more than half of their assets in the microfinance sector. The total volume of fund assets (net asset value) in USD millions is on the X-axis while on the Y-axis we find the share of funds' assets allocated in microfinance investment. Sketched

\footnotetext{
5 The Net Asset Value per share for each fund or sub-fund is determined on the relevant valuation date (usually once or twice a month) by dividing the value of the total assets of a fund / sub-fund less the liabilities by the total number of shares.
} 


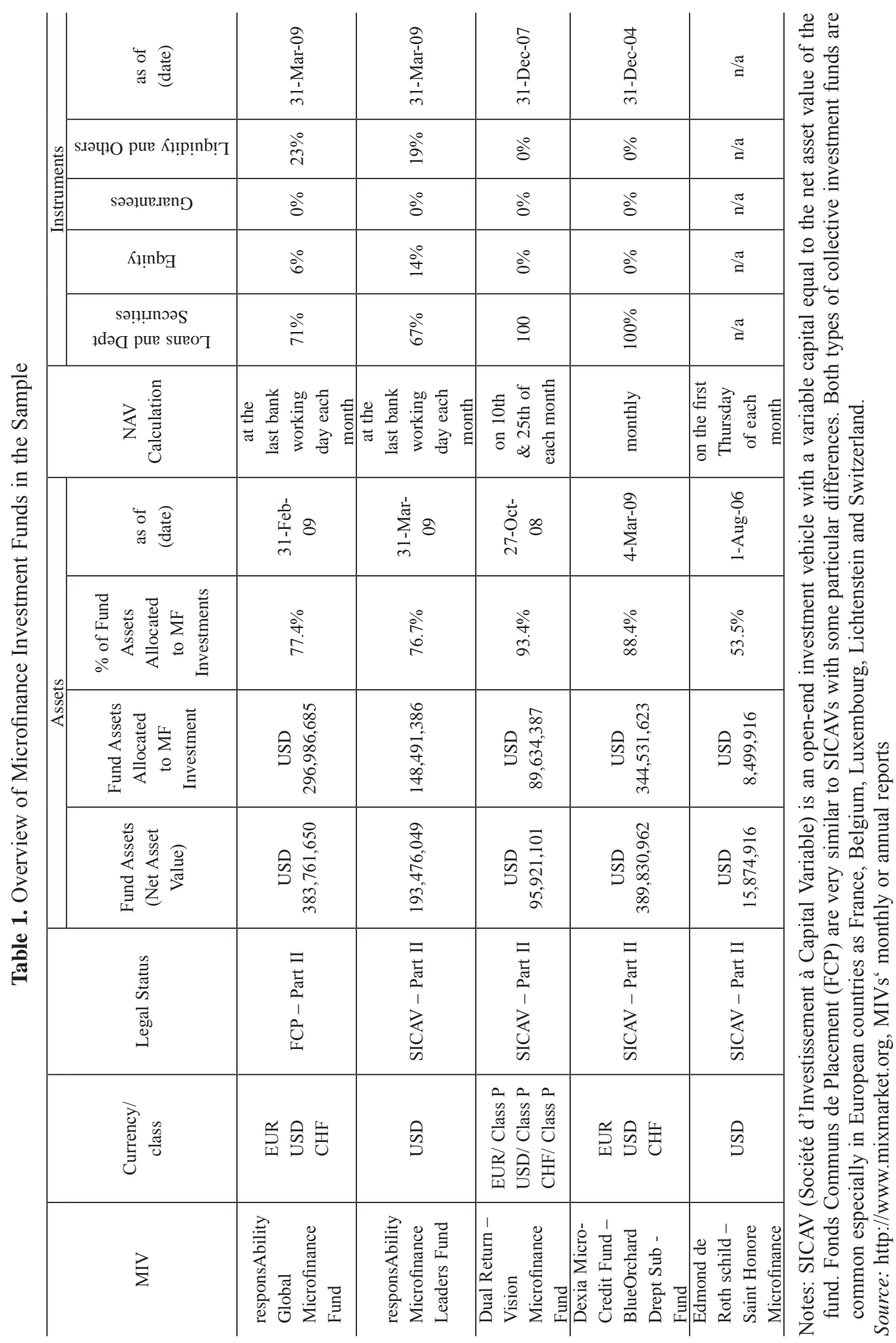


trend line suggests the relationship for studied funds between the total asset volume and microfinance involvement. Dual Return, Dexia and both responsAbility funds allocate more than $70 \%$ of assets in microfinance while the Dual Return-Vision Microfinance Fund places as much as $93.5 \%$ of assets in microfinance (as of October $27^{\text {th }} 2008$ ).

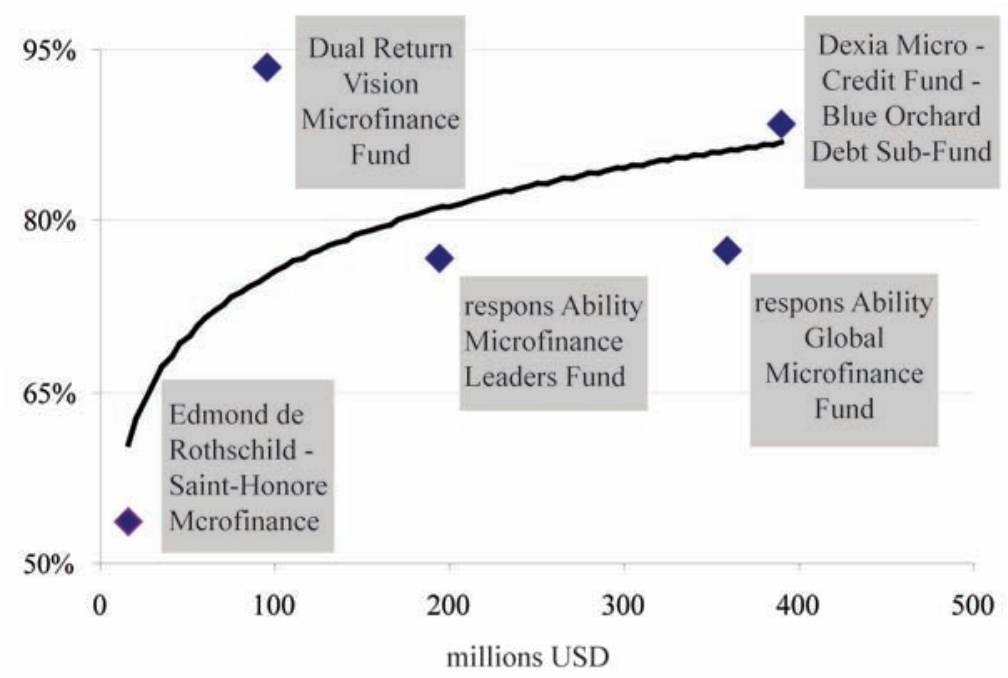

Fig. 1. Fund Assets and Their Share Allocated in Microfinance

Source: http://www.mixmarket.org, MIVs‘ monthly or annual reports, own calculations

From the perspective of funds ${ }^{6}$ social impact each fund reports the estimated number of microlenders reached by the fund, i.e. volume of people that were able to obtain a microloan by one of the MFIs in funds ${ }^{6}$ portfolios thanks to the funding that a particular microfinance institution obtained throughout a fund. ResponsAbility Global Microfinance and Dexia Micro-Credit funds are the largest in terms of assets under management as well as microentrepreneurs reached by the fund. Figure 2 reveals also the average size of microloans accorded by MFIs in portfolio that is generally between USD 1,500-3,000.

The orientation of women customer is typical for the microfinance, nevertheless in case of MFIs within portfolios of microfinance funds in the sample the share of women reaches rather low levels around 55\% (Figure 3). In general, more commercial MFIs focus on urban areas with a high concentration of poor people (despite the fact that the most impoverished are rural areas residents). Urban customers slightly prevail in case of MFIs that are funded on a commercial basis via examined microfinance funds, which suggests that MIVs chose to finance more commercial (and sustainable) MFIs when measured by the share of urban/rural clients. For further discussion of the role of women in MFIs see Bassem (2009). 


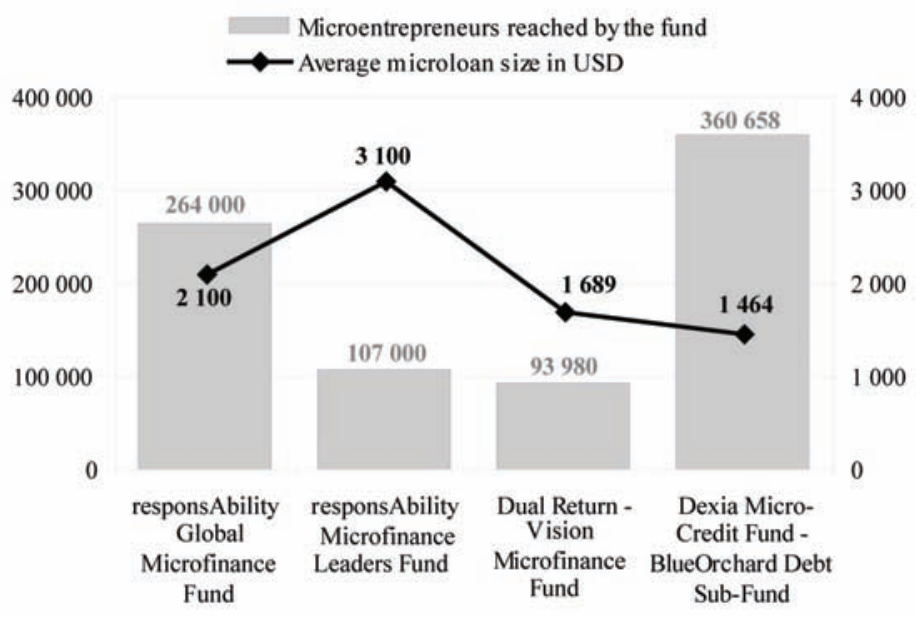

Fig. 2. Microlenders Reached by Funds and Average Microloan Size

Notes: SICAV Figures as of March 2009 for both responsibility funds, April 2009 for the Dual ReturnVision Microfinance Fund, December 2008 for the Dexia Micro-Credit. Data for the Edmond de Rothschild - Saint Honore Microfinance were not available.

Source: MIVs' monthly or annual reports

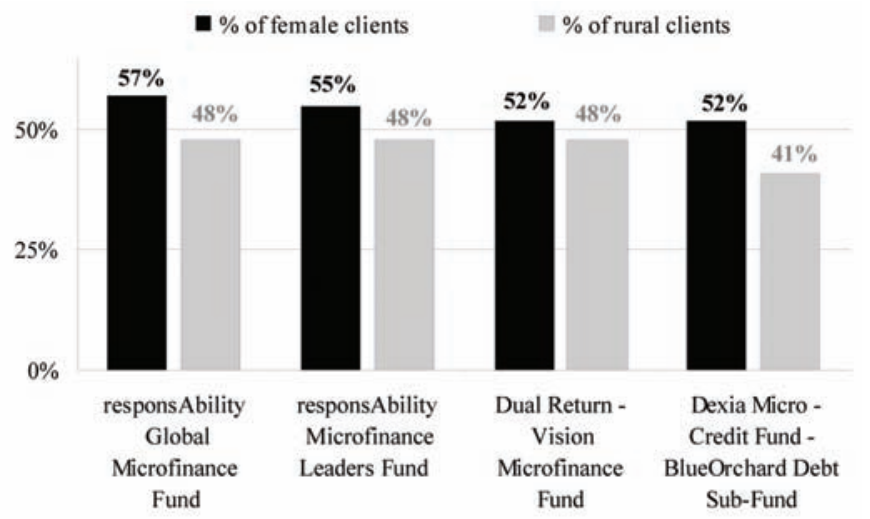

Fig. 3. The Share of Female and Urban Clients

Notes: SICAV Figures as of March 2009 for both responsibility funds, April 2009 for the Dual ReturnVision Microfinance Fund, December 2008 for the Dexia Micro-Credit. Data for the Edmond de Rothschild - Saint Honore Microfinance were not available.

Source: MIVs' monthly or annual reports 


\section{The Analytical Results}

Before examining the proper risk and return characteristics of selected microfinance funds we shall at first examine their performance over the study period from January 2006 until March 2009 against two equity indices as proxies for stock market performance and in the second time against fixed income indices. As a proxy for the overall stock market we have chosen the Morgan Stanley Capital International (MSCI) World Index denominated in USD that is designed to measure equity market performance of developed markets. It seemed interesting to look at the performance of microfinance funds not only in the light of global markets but also compared to securities that share similar characteristics as studied microfinance funds. For that reason, we added the MSCI Emerging Markets Diversified Financials Index to the study as a proxy for the financial companies in emerging countries. The regional focus simulates the additional market risk of such securities compared to developed markets related to political and economic issues as well as currency risks. The MSCI EM Diversified Financials Index covers also regions that are the most represented in portfolios of studied microfinance funds (the index includes countries such as India and Pakistan, followed by Mexico and South American countries as Argentina, Brazil, Chile, Colombia, Peru or Venezuela).

Since the majority of microfinance funds' portfolio is composed of debt instruments we found useful to compare their risk and performance features to fixed income benchmarks as well. As a proxy for global fixed income markets we shall use the Markit iBoxx USD Overall Index comprising corporate bond issues and bonds issued by the U.S. government and government-sponsored agencies. The index is used for the fixed income research, asset allocation and performance evaluation. In order to examine microfinance funds' performance in relation to the emerging bond markets we shall work with the J. P. Morgan Emerging Market Bond Index Plus (EMBI+) that is designed to replicate total returns of traded external debt instruments in the emerging markets.

Bloomberg Financial Services was the source for all indices' data. As a risk-free rate we used the 4-week U.S. Treasury Bill rate, whose data were obtained from the U.S. Department of the Treasury on-line Interest Rate Statistics. Investment funds' monthly returns $r_{i t}$ and returns of chosen market indices $r_{M t}$ were calculated using basic returns

formulas: $r_{i t}=\frac{N A V_{t}-N A V_{t-1}}{N A V_{t-1}}$ and $r_{M t}=\frac{\text { index }_{t}-i n d e x_{t-1}}{\text { index }_{t-1}}$ respectively, where $N A V_{t}$ is the net asset value of a mutual fund $i$ in time $t$ and index $x_{t}$ refers to the level of a given index in time $t$. Since none of the microfinance funds pays dividends and its returns are reinvested the NAVs did not have to be dividend-adjusted.

\subsection{Microfinance Investment Funds' Historical Performance}

From the table 2 with an overview of mean monthly and annual returns of microfinance investment funds and benchmark indices we can see that the best performing fund in terms of average month-on-month return was the Dual Return-Vision Microfinance Fund quoted in US dollars $(+0.5 \% \mathrm{~m} / \mathrm{m})$. The mean monthly return of microfinance 
investment funds were always rather modest but positive and in average $(+0.36 \% \mathrm{~m} / \mathrm{m})$ slightly higher than that one of the risk-free asset $(+0.26 \% \mathrm{~m} / \mathrm{m})$. The MSCI World Index recorded an average monthly return of only $-0.99 \%$ over the same time period. The most obvious reason for this low performance may be the financial crisis that has spread over developed financial markets especially in 2008 and resulted in increased uncertainty and falling stock markets. Suddenly negative growth figures for both MSCI indices from 2008 confirm this hypothesis $(-42.08 \%$ and $-58.04 \%$ for the MSCI World Index and MSCI EM Diversified Financials Index respectively).

The global financial crisis had negative effects linked to increased risk aversion on emerging bond markets (as proxied by the J. P. Morgan Emerging Market Bond Index Plus that dropped $-9.70 \%$ ) while global bond markets represented among our benchmarks the most safe investment possibility and profited from increased demand. Markit iBoxx USD Overall Index reached an annual return of $6.53 \%$ in 2008, while the average of MIVs in the sample was comparable $+5.37 \%$. Annual returns for microfinance funds over the period 2006-2008 slowly increased on a year-on-year basis as these funds got more mature and the microfinance movement gained more interest. On the other hand, it is questionable whether the global financial crisis will not have repercussions on the least developed economies where MFIs act only later on during 2009 and 2010.

\subsection{Risk and Performance Measures}

Pure analysis of historical returns of studied microfinance funds against benchmark indices, however, does not tell us much about the risk of the underlying investment. In order to evaluate both the performance and risk character of microfinance investment funds we shall use three risk measures, the standard deviation of returns of a portfolio, the historical portfolio beta coefficient and the R-squared of a portfolio as well as three performance measures largely adopted in the financial literature - so called Jensen's alpha, the Sharpe ratio and the Treynor ratio. In the rest of this section we will report our results with respect to these indicators.

\subsubsection{Risk Measures}

The results provided in the table 3 show that microfinance portfolios in our sample generated reasonable average returns with moderate volatility from January 2006 to March 2009 and during the recent bear market. In terms of the total risk measured by the standard deviation of monthly returns studied microfinance investment funds recorded very low levels of deviation (in average $+0.32 \%$ ) compared to both the MSCI World equity index as well as against the sectoral MSCI EM Diversified Financials that posted $+10.62 \%$ standard deviation in monthly returns over the same study period. In regard to both fixed income reference indices, while MIVs' monthly returns were at about the same levels, the standard deviations of MIVs' monthly returns were significantly lower than recorded $1.38 \%$ and $3.26 \%$ in case of the Markit iBoxx USD Overall Index and J. P. Morgan EMBI+ respectively. In addition, all funds in the sample have developed in a rather homogeneous matter and we have not witnessed any outlier observation. 
Table 2. Mean Monthly and Total p.a. Returns of Microfinance Investment Funds and Benchmark Indices

\begin{tabular}{|c|c|c|c|c|c|}
\hline \multirow{2}{*}{ MIV } & \multirow{2}{*}{ Currency / Class } & \multirow{2}{*}{$\begin{array}{l}\text { Mean } \\
\text { Monthly } \\
\text { Return }\end{array}$} & \multicolumn{3}{|c|}{ Total Return p.a. } \\
\hline & & & 2006 & 2007 & 2008 \\
\hline \multirow{3}{*}{$\begin{array}{l}\text { responsAbility } \\
\text { Global Microfinance } \\
\text { Fund }\end{array}$} & EUR & $0.41 \%$ & $2.70 \%$ & $6.31 \%$ & $6.88 \%$ \\
\hline & USD & $0.49 \%$ & $5.07 \%$ & $7.70 \%$ & $6.44 \%$ \\
\hline & $\mathrm{CHF}$ & $0.27 \%$ & $1.10 \%$ & $4.36 \%$ & $5.11 \%$ \\
\hline $\begin{array}{l}\text { responsAbility } \\
\text { Microfinance Leaders } \\
\text { Fund }\end{array}$ & USD & $0.48 \%$ & $0.34 \%$ & $6.03 \%$ & $7.51 \%$ \\
\hline \multirow{3}{*}{$\begin{array}{l}\text { Dual Return - Vision } \\
\text { Microfinance Fund }\end{array}$} & USD / Class P & $0.50 \%$ & $0.18 \%$ & $5.51 \%$ & $4.31 \%$ \\
\hline & EUR / Class P & $0.29 \%$ & $0.09 \%$ & $3.11 \%$ & $5.60 \%$ \\
\hline & CHF / Class P & $0.15 \%$ & $-0.08 \%$ & $1.36 \%$ & $3.55 \%$ \\
\hline \multirow{3}{*}{$\begin{array}{l}\text { Dexia Micro-Credit } \\
\text { Fund - BlueOrchard } \\
\text { Debt Sub-Fund }\end{array}$} & EUR & $0.40 \%$ & $0.34 \%$ & $4.83 \%$ & $5.90 \%$ \\
\hline & $\mathrm{CHF}$ & $0.26 \%$ & $0.38 \%$ & $2.94 \%$ & $4.21 \%$ \\
\hline & USD & $0.48 \%$ & $1.11 \%$ & $5.89 \%$ & $5.64 \%$ \\
\hline $\begin{array}{l}\text { Edmond de } \\
\text { Rothschild - Saint- } \\
\text { Honore Microfinance }\end{array}$ & EUR & $0.24 \%$ & $0.25 \%$ & $2.27 \%$ & $3.93 \%$ \\
\hline \multicolumn{2}{|c|}{ Mean of selected MIVs } & $0.36 \%$ & $1.05 \%$ & $4.57 \%$ & $5.37 \%$ \\
\hline \multicolumn{6}{|l|}{ Benchmark indices } \\
\hline \multicolumn{2}{|l|}{ MSCI World Index } & $-0.99 \%$ & $17.95 \%$ & $7.09 \%$ & $-42.08 \%$ \\
\hline \multicolumn{2}{|c|}{$\begin{array}{l}\text { MSCI Emerging Markets Diversified } \\
\text { Financials Index }\end{array}$} & $-0.40 \%$ & $12.16 \%$ & $55.08 \%$ & $-58.04 \%$ \\
\hline \multicolumn{2}{|c|}{ iBoxx USD Overall Index } & $0.41 \%$ & $3.71 \%$ & $7.54 \%$ & $6.53 \%$ \\
\hline \multicolumn{2}{|c|}{$\begin{array}{l}\text { J.P. Morgan Emerging Bond Index } \\
(\mathrm{EMBI}+)\end{array}$} & $0.27 \%$ & $10.48 \%$ & $6.45 \%$ & $-9.70 \%$ \\
\hline \multicolumn{2}{|l|}{ Risk-free asset } & & & & \\
\hline \multicolumn{2}{|c|}{ 4-Week U.S. Treasury Bill } & $0.26 \%$ & & & \\
\hline
\end{tabular}

Source: own calculations on data from Bloomberg 
Table 3. Standard Deviation in Monthly Returns

\begin{tabular}{|c|c|c|c|}
\hline MIV & $\begin{array}{l}\text { Currency / } \\
\text { Class }\end{array}$ & $\begin{array}{l}\text { Mean Monthly } \\
\text { Return }\end{array}$ & $\begin{array}{l}\text { Standard Deviation in } \\
\text { Monthly Returns }\end{array}$ \\
\hline \multirow{3}{*}{$\begin{array}{l}\text { responsAbility Global } \\
\text { Microfinance Fund }\end{array}$} & EUR & $0.41 \%$ & $0.40 \%$ \\
\hline & USD & $0.49 \%$ & $0.41 \%$ \\
\hline & $\mathrm{CHF}$ & $0.27 \%$ & $0.40 \%$ \\
\hline $\begin{array}{l}\text { responsAbility Microfinance } \\
\text { Leaders Fund }\end{array}$ & USD & $0.48 \%$ & $0.43 \%$ \\
\hline \multirow{3}{*}{$\begin{array}{l}\text { Dual Return - Vision } \\
\text { Microfinance Fund }\end{array}$} & USD / Class P & $0.50 \%$ & $0.86 \%$ \\
\hline & EUR / Class P & $0.29 \%$ & $0.18 \%$ \\
\hline & CHF / Class P & $0.15 \%$ & $0.17 \%$ \\
\hline \multirow{3}{*}{$\begin{array}{l}\text { Dexia Micro-Credit Fund - } \\
\text { BlueOrchard Debt Sub-Fund }\end{array}$} & EUR & $0.40 \%$ & $0.15 \%$ \\
\hline & $\mathrm{CHF}$ & $0.26 \%$ & $0.15 \%$ \\
\hline & USD & $0.48 \%$ & $0.21 \%$ \\
\hline $\begin{array}{l}\text { Edmond de Rothschild - } \\
\text { Saint-Honore Microfinance }\end{array}$ & EUR & $0.24 \%$ & $0.21 \%$ \\
\hline \multicolumn{2}{|l|}{ Mean of selected MIVs } & $0.36 \%$ & $0.32 \%$ \\
\hline \multicolumn{4}{|l|}{ Benchmark indices } \\
\hline \multicolumn{2}{|l|}{ MSCI World Index } & $-0.99 \%$ & $5.35 \%$ \\
\hline \multicolumn{2}{|c|}{$\begin{array}{l}\text { MSCI Emerging Markets Diversified Financials } \\
\text { Index }\end{array}$} & $-0.40 \%$ & $10.62 \%$ \\
\hline \multicolumn{2}{|l|}{ iBoxx USD Overall Index } & $0.41 \%$ & $1.38 \%$ \\
\hline \multicolumn{2}{|c|}{ J. P. Morgan Emerging Bond Index (EMBI+) } & $0.27 \%$ & $3.26 \%$ \\
\hline \multicolumn{2}{|l|}{ Risk-free asset } & & \\
\hline \multicolumn{2}{|l|}{ 4-Week U.S. Treasury Bill } & $0.26 \%$ & $0.15 \%$ \\
\hline
\end{tabular}

Source: own calculations on data from Bloomberg 
The classical measure of risk is beta coefficient, see Janda (1994). Ordinary least squares estimates of beta obtained by regressing the risk-free rate adjusted returns of studied microfinance investment funds against excess returns of four selected market portfolios (world indices) are presented in table 4. Beta coefficient reflects the sensitivity of MIVs' returns to returns of a market portfolio and reveals how the asset is correlated to the performance of a benchmark index. Beta is a measure of a systematic (or non-diversifiable) risk of an asset within a broader portfolio and in a well-diversified portfolio it creates almost all of the risk. All funds but one (which was not significant at elected significance levels) recorded negative beta against the MSCI World Index reaching an average of statistically significant betas of -0.024 . This result suggests that investment funds in the sample do not show any positive correlation to world equity markets (and on the contrary move in a slightly antagonistic matter). Studied MIVs neither tracked with the emerging equity markets as represented by the MSCI EM Diversified Financials, nevertheless only four out of eleven funds' or sub-funds' results for beta were significant at at least $10 \%$ level of significance. Our regression model did not seem to hold when fixed income benchmarks were used ending with only one statistically significant beta coefficient each time.

Observed R-squared measures resulting from the same regression and reflecting the tightness of the correlation of MIVs' and benchmark's returns reached low levels with respect to all indices. In case of the MSCI World in average about $12 \%$ of the variability in microfinance fund's returns could be attributed to the moves of the benchmark index. Average R-squared reached even lower levels with respect to emerging equity markets (6.69\% for the MSCI EM Diversified Financials) as well as for both bond indices indicating that there is a low correlation in monthly returns of all benchmark indices and microfinance investment funds.

The study period tracks the development of the financial markets performance over little more than last three years when we had witnessed growing stock prices as well as massive sell-outs due to the global uncertainty caused by the financial crisis. With respect to this fact, we may ask whether the beta coefficient representing the direction of correlation of microfinance funds ' performance to global and emerging markets had remained approximately equal within both periods. In order to account for these two rather clear trends in the movement of especially benchmark equity indices we shall carry out the Chow test for the presence of a structural break in time series. For each fund we divide available performance data set in two periods of 22 and 17 observations where as the split point we take the end of October 2007 when both MSCI World and MSCI EM Diversified Financials indices reached their maximum values (in terms of month-on-month returns and within our study period from January $31^{\text {st }} 2006$ until

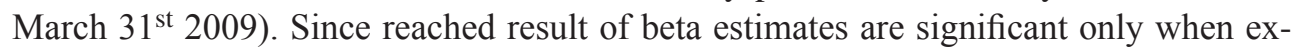
amining the correlation to world equity markets represented by the MSCI World Index (nine statistically significant estimates at at least 10\% level out of 11 funds in the sample), we shall undertake the analysis of the presence of the structural break in MIV's performance data with respect to the MSCI World. We will test the null hypothesis of no structural break in data series, i.e. 


\begin{tabular}{|c|c|c|c|c|c|c|c|c|c|c|c|c|c|c|c|}
\hline & & $\underset{\stackrel{\circ}{+}}{\stackrel{+}{+}}$ & 仓ें & $\begin{array}{l}\stackrel{\circ}{ } \\
\text { ஸे }\end{array}$ & $\begin{array}{l}\stackrel{0}{\infty} \\
\infty \\
\infty \\
\dot{0}\end{array}$ & $\stackrel{\circ}{\stackrel{9}{9}}$ & $\begin{array}{l}\stackrel{\circ}{\stackrel{0}{0}} \\
\stackrel{+}{+}\end{array}$ & $\begin{array}{l}\stackrel{\leftrightarrow}{\sigma} \\
\stackrel{+}{\circ}\end{array}$ & 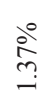 & $\begin{array}{l}\stackrel{0}{0} \\
\stackrel{0}{0} \\
0\end{array}$ & $\begin{array}{l}\stackrel{\circ}{\hat{े}} \\
\text { ì }\end{array}$ & $\begin{array}{l}\text { dे } \\
\text { in }\end{array}$ & $\stackrel{\stackrel{े}{+}}{+}$ & & \\
\hline & $\left|\begin{array}{l}0 \\
\hat{\alpha} \\
\dot{\alpha}\end{array}\right|$ & & & & * & & & & & & & & & & \\
\hline$\sum_{i=1}^{ \pm}$ & 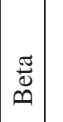 & $\begin{array}{l}\overrightarrow{0} \\
0 \\
0 \\
0 \\
i\end{array}$ & $\begin{array}{l}\overrightarrow{\tilde{N}} \\
\stackrel{\tilde{\sigma}}{0} \\
\dot{\varphi}\end{array}$ & 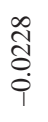 & 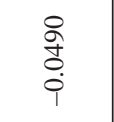 & $\begin{array}{l}\text { Oे } \\
\text { O. } \\
\text { : }\end{array}$ & $\begin{array}{l}\infty \\
\stackrel{0}{0} \\
0 \\
0 \\
i\end{array}$ & $\begin{array}{l}\mathscr{\Omega} \\
\stackrel{\sigma}{\sigma} \\
0 \\
0\end{array}$ & $\begin{array}{l}\text { वे } \\
\stackrel{0}{0} \\
\dot{0}\end{array}$ & $\begin{array}{l}\text { ठิ } \\
\text { ठุ. } \\
\text { i }\end{array}$ & $\begin{array}{l}\text { 몽 } \\
\stackrel{-}{0} \\
\stackrel{0}{0}\end{array}$ & $\begin{array}{l}n \\
\stackrel{a}{0} \\
0 \\
0 \\
i\end{array}$ & $\begin{array}{l}0 \\
\text { m} \\
0 \\
0 \\
0\end{array}$ & & \\
\hline 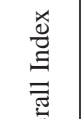 & & iे & $\begin{array}{l}\stackrel{0}{\stackrel{0}{I}} \\
\stackrel{-}{=}\end{array}$ & $\begin{array}{l}\stackrel{0}{+} \\
\text { dे } \\
\text { i }\end{array}$ & $\frac{\partial}{\vec{\lambda}}$ & $\begin{array}{l}\stackrel{0}{\circ} \\
\stackrel{\sim}{1}\end{array}$ & 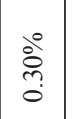 & $\frac{i}{i}$ & ڤั̀ & $\stackrel{\stackrel{े}{~}}{\stackrel{-}{7}}$ & $\begin{array}{l}\stackrel{\circ}{\vec{n}} \\
\stackrel{\sim}{\beth}\end{array}$ & 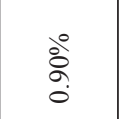 & $\begin{array}{l}\stackrel{\circ}{\grave{n}} \\
\stackrel{i}{i}\end{array}$ & & \\
\hline రั & 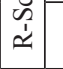 & & & & & & & & & & $*$ & & & & \\
\hline 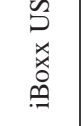 & 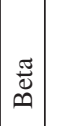 & 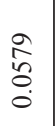 & $\begin{array}{l}\tilde{N} \\
\tilde{\tilde{\sigma}} \\
0 \\
0\end{array}$ & $\begin{array}{l}\text { 悉 } \\
0 \\
0\end{array}$ & $\begin{array}{l}\hat{7} \\
\stackrel{0}{0} \\
\dot{0}\end{array}$ & 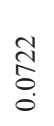 & $\begin{array}{l}\text { స̃ } \\
0 \\
0 \\
i\end{array}$ & 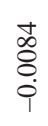 & $\begin{array}{l}\overrightarrow{0} \\
\stackrel{0}{0} \\
\dot{0}\end{array}$ & $\begin{array}{l}\text { 염 } \\
\stackrel{0}{0} \\
0\end{array}$ & 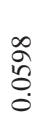 & $\begin{array}{l}\stackrel{2}{\circ} \\
0 \\
0 \\
\end{array}$ & 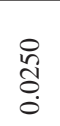 & & $\overline{0}$ \\
\hline $\begin{array}{l}\overrightarrow{0} \\
\stackrel{.}{W_{n}}\end{array}$ & $\dot{\sigma}$ & 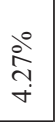 & $\begin{array}{l}\stackrel{0}{\infty} \\
\infty \\
\dot{n}\end{array}$ & $\begin{array}{l}\stackrel{0}{+} \\
\stackrel{+}{+}\end{array}$ & $\begin{array}{l}\stackrel{0}{0} \\
\stackrel{i}{0}\end{array}$ & $\begin{array}{l}\stackrel{0}{\circ} \\
\stackrel{\circ}{+} \\
+\end{array}$ & ڤั̀ & $\frac{\stackrel{\circ}{a}}{\stackrel{a}{I}}$ & $\frac{\partial^{\circ}}{\dot{\sigma}}$ & $\stackrel{\stackrel{\circ}{7}}{=}$ & $\begin{array}{l}\stackrel{0}{0} \\
\stackrel{0}{0} \\
0\end{array}$ & $\stackrel{\stackrel{0}{ٍ}}{\stackrel{\infty}{\infty}}$ & ठ̊̊. & & $\frac{\partial^{\circ}}{0}$ \\
\hline$\stackrel{g}{\Xi}$ & $\begin{array}{l}\alpha \\
\stackrel{1}{\alpha} \\
\check{\sim}\end{array}$ & & & & * & & * & $\stackrel{*}{*}$ & & & & * & & & 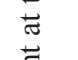 \\
\hline 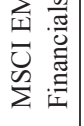 & 莺 & $\begin{array}{l}0 \\
0 \\
0 \\
\dot{\varphi}\end{array}$ & $\begin{array}{l}8 \\
\stackrel{0}{0} \\
\stackrel{0}{0} \\
\end{array}$ & $\begin{array}{l}\overrightarrow{8} \\
\dot{0} \\
\dot{\varphi}\end{array}$ & $\begin{array}{l}\stackrel{2}{\Xi} \\
\stackrel{0}{0}\end{array}$ & $\begin{array}{l}0 \\
0 \\
0 \\
0 \\
0\end{array}$ & 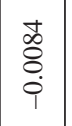 & $\begin{array}{l}8 \\
\stackrel{0}{0} \\
0 \\
0\end{array}$ & 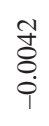 & 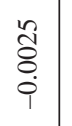 & $\begin{array}{l}0 \\
\stackrel{0}{8} \\
\stackrel{0}{0}\end{array}$ & 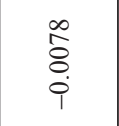 & $\begin{array}{l}\text { N้ } \\
\text { ơ } \\
\text { iे }\end{array}$ & $\begin{array}{l}8 \\
0 \\
0 \\
0 \\
\end{array}$ & 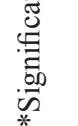 \\
\hline & & $\begin{array}{l}\circ \\
\stackrel{\circ}{\circ} \\
=\end{array}$ & $\begin{array}{l}\stackrel{0}{0} \\
\infty \\
\stackrel{0}{\Xi} \\
\Xi\end{array}$ & $\begin{array}{l}\stackrel{0}{0} \\
\text { o } \\
\text { i } \\
\end{array}$ & $\frac{\stackrel{\circ}{\circ}}{\stackrel{2}{n}}$ & $\begin{array}{l}\stackrel{0}{0} \\
\vdots \\
\infty \\
i\end{array}$ & $\frac{\stackrel{\circ}{\text { oे }}}{\text { ते }}$ & $\begin{array}{l}\stackrel{\circ}{\grave{d}} \\
\text { ते }\end{array}$ & $\begin{array}{l}\stackrel{0}{\circ} \\
\infty \\
\stackrel{1}{~}\end{array}$ & $\stackrel{\circ}{\stackrel{\circ}{i}}$ & $\begin{array}{l}\stackrel{0}{\circ} \\
\stackrel{-}{\leftrightarrows}\end{array}$ & 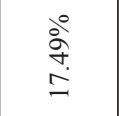 & $\begin{array}{l}\stackrel{0}{i} \\
i \stackrel{n}{]} \\
\text { in }\end{array}$ & & $\begin{array}{l}* \\
\ddot{\bar{d}} \\
\ddot{\vec{e}}\end{array}$ \\
\hline$\overbrace{\Xi}^{\infty}$ & $\mid \begin{array}{l}\dot{\check{n}} \\
\dot{\alpha} \\
\check{\sim}\end{array}$ & $*$ & $*$ & $\stackrel{*}{*}$ & * & & $\begin{array}{l}\stackrel{*}{*} \\
* \\
*\end{array}$ & $\begin{array}{l}* \\
* \\
*\end{array}$ & $*$ & $*$ & & $\begin{array}{l}* \\
* \\
*\end{array}$ & & & \\
\hline $\begin{array}{l}3 \\
0 \\
\mathscr{N}^{n}\end{array}$ & 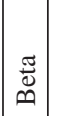 & 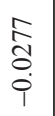 & $\begin{array}{c}\overrightarrow{0} \\
\tilde{\Delta} \\
0 \\
\dot{\varphi}\end{array}$ & 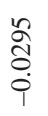 & 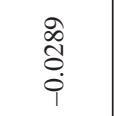 & $\begin{array}{l}\mathscr{M} \\
\stackrel{0}{ } \\
0 \\
0\end{array}$ & 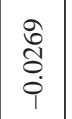 & $\begin{array}{l}\infty \\
0 \\
0 \\
0 \\
0 \\
0\end{array}$ & $\begin{array}{l}\infty \\
\infty \\
\stackrel{1}{0} \\
0 \\
0 \\
0\end{array}$ & $\begin{array}{l}\hat{a} \\
\stackrel{0}{0} \\
\stackrel{0}{0}\end{array}$ & $\begin{array}{l}\text { 年 } \\
8 \\
0 \\
0\end{array}$ & 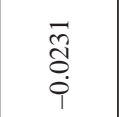 & $\begin{array}{l}\stackrel{\infty}{=} \\
\stackrel{0}{0} \\
\stackrel{1}{0}\end{array}$ & $\begin{array}{l}\text { 莳 } \\
\text { Oे } \\
\stackrel{1}{1}\end{array}$ & 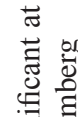 \\
\hline 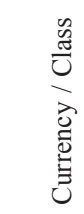 & & 总 & คి & 嵒 & के & $\begin{array}{l}0 \\
w \\
0 \\
\frac{\sigma}{0} \\
0 \\
0 \\
0 \\
0\end{array}$ & 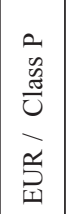 & 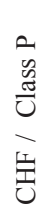 & 蛋 & 志 & 命 & 节 & & 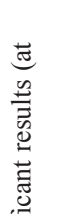 & 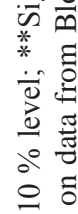 \\
\hline 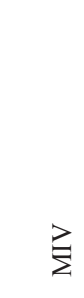 & & & 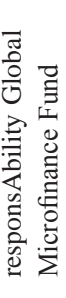 & & 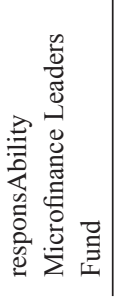 & & 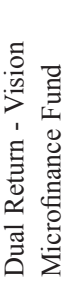 & & & 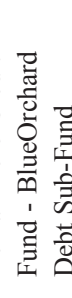 & & 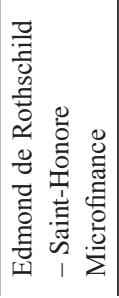 & 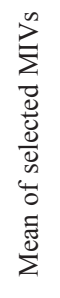 & 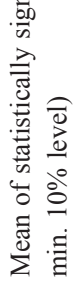 & 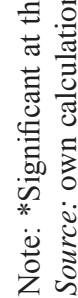 \\
\hline
\end{tabular}




$$
\begin{gathered}
H_{0}:\left(r_{i t}-r_{f t}\right)^{(1)}=\alpha_{i}^{(1)}+\beta_{i}^{(1)} \cdot\left(r_{M t}-r_{f t}\right)^{(1)}+\varepsilon_{t}^{(1)}, \\
\left(r_{i t}-r_{f t}\right)^{(2)}=\alpha_{i}^{(1)}+\beta_{i}^{(1)} \cdot\left(r_{M t}-r_{f t}\right)^{(2)}+\varepsilon_{t}^{(2)}
\end{gathered}
$$

against the alternative depicted by equation (2)

$$
\begin{gathered}
H_{A}:\left(r_{i t}-r_{f t}\right)^{(1)}=\alpha_{i}^{(1)}+\beta_{i}^{(1)} \cdot\left(r_{M t}-r_{f t}\right)^{(1)}+\varepsilon_{t}^{(1)}, \\
\left(r_{i t}-r_{f t}\right)^{(2)}=\alpha_{i}^{(2)}+\beta_{i}^{(2)} \cdot\left(r_{M t}-r_{f t}\right)^{(2)}+\varepsilon_{t}^{(2)} .
\end{gathered}
$$

The Chow test could not exclude the stability of estimates of $\alpha$ and $\beta$ within the two periods for both responsAbility Global Microfinance and Leaders funds (neither at broader $10 \%$ level of significance). All four funds/sub-funds previously proved a negative close-to-zero beta indicating zero correlation to world equity markets (represented by the MSCI World) and may therefore be a valuable tool to diversify the portfolio and lower its overall risk.

On the other hand, the hypothesis of no structural break shown by equation (1) was rejected (see table 5 in bold) for all classes of the Dual Return-Vision Microfinance and Dexia Micro-Credit funds as well as for the Edmond de Rothschild - Saint Honore Microfinance at 5\% (or 1\%) significance level. The Chow test suggests that either alpha or beta (or both) had changed from one period to another and might have been therefore affected by the rise and fall effect of stock markets. We shall, therefore, run separate linear regressions for each fund for two time periods (first period: January 2006 - October 2007; second period: November 2007 - March 2009) and asses OLS estimates of the model parameters in the first and second period, i.e. $\hat{\alpha}^{(1)}, \hat{\alpha}^{(2)}, \hat{\beta}^{(1)}, \hat{\beta}^{(2)}$, to be able to evaluate the difference in beta and alpha estimates in respective time periods.

Unfortunately, only few beta estimates in both periods were statistically significant. Nevertheless, slight changes in beta estimates were recorded and some positive estimates of beta were reached as well, but all estimates are still close to zero, which should therefore point to zero symmetric risk due to zero correlation of microfinance investment funds ${ }^{\text {c }}$ portfolios to world equity market. Obtained results are therefore in line with our hypothesis of non-exposure of MIV's to world equity markets as represented by the MSCI World.

In order to explain the structural break in estimates after October 2007 indicated by the Chow test we shall focus on the intercept estimates where we see important changes in the Jensen's alpha from negative to positive figures (move of the average of statistically significant estimates at minimum $10 \%$ level of significance from $-0.11 \%$ in the first period to $0.31 \%$ for the later period). We shall make some remarks on this development below. 


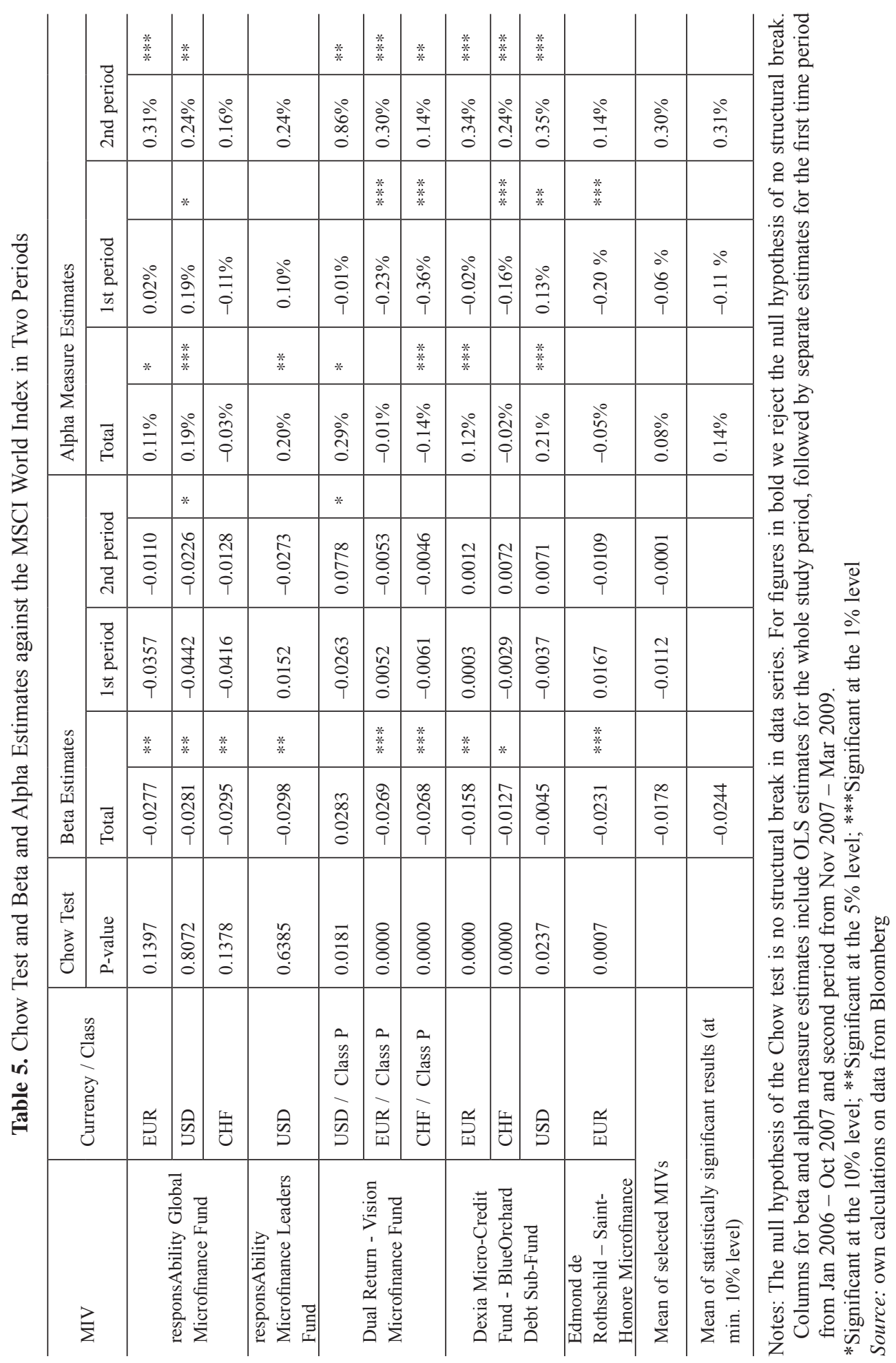




\subsubsection{Performance Measures}

The systematic risk-adjusted monthly performance of studied MIVs against given benchmark indices were measured by the Jensen's alpha that stems from the above described linear regression. With respect to this measure microfinance investment funds in average outperformed all given benchmarks by 14-16 basis points no matter neither the nature nor the region of investments (mean of statistically significant results at minimum 10\% significance level). Among the statistically significant results the only fund with negative Jensen's alpha (with respect to all indices) was the Swiss franc-denominated Dual Return - Vision Microfinance Fund (see table 6).

The two period analysis shown above revealed, however, that there had been a significant change in alpha estimates (i.e. excess monthly returns of MIVs) between the two time intervals. Mean of statistically significant estimates of alpha was $-0.11 \%$ (table 5 ) in the first period, which means that in times of positive sentiment on global markets monthly returns of microfinance investment funds in the sample slightly lagged behind returns of the MSCI World. Conversely, in time of decreasing markets microfinance funds' shares have not decreased in their value and recorded stable returns. Consequently, in terms of monthly returns they significantly outperformed (in average by 31 basis points $\mathrm{m} / \mathrm{m}$ ) the world equity market represented by the MSCI World. The excess return over the benchmark portfolio should be attributed to both moderately growing microfinance funds on one hand, and to a great extent falling stock markets on the other hand. Nevertheless, as it was mentioned earlier, the negative effect of the financial crisis may appear in the sector only later on. And since the global recession that followed the financial crisis is not over yet and time series are rather short, it's too early to sum up that the microfinance segment in terms of its returns was not touched by global affairs.

Nevertheless, as an inconsistency in alpha estimates between the first and second periods was registered, we may not rely on alpha estimates from the first overall model (suggesting positive and on average rather important excess returns of MIVs over benchmark indices) in implications we make.

Eight out of eleven observed microfinance investment funds reached a positive Sharpe ratio that puts in relation the mean and the standard deviation of a differential return of a portfolio against a given benchmark. The average for all funds exceeded all benchmark indices. Both equity benchmarks' Sharpe ratios representing an excess return compensating for the additional risk investor assumes when holding a riskier asset (i.e. other than the risk-free 4-week U.S. Treasury Bill) ended negative while the J.P. Morgan EMBI+ index recorded a Sharpe ratio close to zero. Positive Sharpe ratio of Markit iBoxx Overall bond index as well as selected MIVs is highly due to low standard deviations in returns (table 3 ) that have a direct effect of the ratio.

Table 7 reveals that some microfinance funds (e.g. Euro and U.S. dollar responsAbility Global Microfinance funds with respect to both equity indices and EMBI+, but also other funds) recorded a negative Treynor ratio (i.e. punishment in terms of added negative returns for an investor who chooses to invest in a riskier asset). All that despite the fact that their Jensen's measures were positive pointing to positive added returns of 
portfolios above the expected returns compensating for the symmetric risk. The inconsistency in results seams to stem from the way the Treynor measure is calculated (ratio of the excess returns of a portfolio (against the risk-free rate) with respect to portfolio's systematic risk exposure given by estimated beta). The Treynor measure is very sensitive to the beta in denominator and according to Hubner (2005) it may provide unstable and imprecise performance measures for market neutral funds because of the risk of measurement error. For funds with negative betas, the Treynor Ratio is, in effect, inapplicable as it attributes a negative performance to funds with positive abnormal returns (Hubner 2005). For this reason we prefer to rely on the alpha measure that equally measures excess returns of a portfolio in relation to its systematic risk but it is not computed directly on the basis of beta.

Table 6. Portfolio Jensen`s Alphas

\begin{tabular}{|c|c|c|c|c|c|c|c|c|}
\hline MIV & $\begin{array}{l}\text { Currency / } \\
\text { Class }\end{array}$ & \multicolumn{2}{|c|}{$\begin{array}{l}\text { MSCI World } \\
\text { Index }\end{array}$} & \multicolumn{2}{|c|}{$\begin{array}{c}\text { MSCI EM } \\
\text { Diversified } \\
\text { Financials } \\
\text { Index }\end{array}$} & \multicolumn{2}{|c|}{$\begin{array}{l}\text { iBoxx USD } \\
\text { Overall Index }\end{array}$} & \multirow{2}{*}{$\begin{array}{c}\text { EMBI+ } \\
0.15 \% * *\end{array}$} \\
\hline \multirow{3}{*}{$\begin{array}{l}\text { responsAbility Global } \\
\text { Microfinance Fund }\end{array}$} & EUR & $0.11 \%$ & * & $0.14 \%$ & $* *$ & $0.14 \%$ & * & \\
\hline & USD & $0.19 \%$ & $* * *$ & $0.22 \%$ & $* * *$ & $0.22 \%$ & $* * *$ & $0.23 \% * * *$ \\
\hline & $\mathrm{CHF}$ & $-0.03 \%$ & & $0.00 \%$ & & $0.00 \%$ & & $0.01 \%$ \\
\hline $\begin{array}{l}\text { responsAbility } \\
\text { Microfinance Leaders } \\
\text { Fund }\end{array}$ & USD & $0.20 \%$ & $* *$ & $0.24 \%$ & $* * *$ & $0.26 \%$ & $* * *$ & $0.25 \% * * *$ \\
\hline \multirow{3}{*}{$\begin{array}{l}\text { Dual Return - Vision } \\
\text { Microfinance Fund }\end{array}$} & USD / Class P & $0.29 \%$ & * & $0.26 \%$ & * & $0.23 \%$ & & $0.25 \%$ \\
\hline & EUR / Class P & $-0.01 \%$ & & $0.03 \%$ & & $0.04 \%$ & & $0.04 \%$ \\
\hline & CHF / Class P & $-0.14 \%$ & $* * *$ & $-0.11 \%$ & $* *$ & $-0.10 \%$ & * & $-0.10 \%-*$ \\
\hline \multirow{3}{*}{$\begin{array}{l}\text { Dexia Micro-Credit } \\
\text { Fund - BlueOrchard Debt } \\
\text { Sub-Fund }\end{array}$} & EUR & $0.12 \%$ & $* * *$ & $0.13 \%$ & $* * *$ & $0.13 \%$ & $* * *$ & $0.14 \% * * *$ \\
\hline & $\mathrm{CHF}$ & $-0.02 \%$ & & $0.00 \%$ & & $0.00 \%$ & & $0.00 \%$ \\
\hline & USD & $0.21 \%$ & $* * *$ & $0.22 \%$ & $* * *$ & $0.21 \%$ & $* * *$ & $0.22 \% * * *$ \\
\hline $\begin{array}{l}\text { Edmond de Rothschild } \\
\text { - Saint-Honore } \\
\text { Microfinance }\end{array}$ & EUR & $-0.05 \%$ & & $-0.03 \%$ & & $-0.02 \%$ & & $-0.02 \%$ \\
\hline \multicolumn{2}{|l|}{ Mean of selected MIVs } & $0.08 \%$ & & $0.10 \%$ & & $0.10 \%$ & & $0.10 \%$ \\
\hline \multicolumn{2}{|c|}{$\begin{array}{l}\text { Mean of statistically significant results (at } \\
\text { min. } 10 \% \text { level) }\end{array}$} & $0.14 \%$ & & $0.16 \%$ & & $0.14 \%$ & & $0.15 \%$ \\
\hline
\end{tabular}

Note: *Significant at the $10 \%$ level; **Significant at the $5 \%$ level; ***Significant at the $1 \%$ level Source: own calculations on data from Bloomberg 
Table 7. Portfolio Sharpe and Treynor Ratios

\begin{tabular}{|c|c|c|c|c|c|c|}
\hline \multirow[b]{2}{*}{ MIV } & \multirow[b]{2}{*}{$\begin{array}{l}\text { Currency / } \\
\text { Class }\end{array}$} & \multirow[b]{2}{*}{$\begin{array}{l}\text { Sharpe } \\
\text { Ratio }\end{array}$} & \multicolumn{4}{|c|}{ Treynor Ratio } \\
\hline & & & $\begin{array}{l}\text { MSCI } \\
\text { World } \\
\text { Index }\end{array}$ & $\begin{array}{l}\text { MSCI EM } \\
\text { Diversified } \\
\text { Financials } \\
\text { Index }\end{array}$ & $\begin{array}{l}\text { iBoxx } \\
\text { USD } \\
\text { Overall } \\
\text { Index }\end{array}$ & EMBI+ \\
\hline \multirow{3}{*}{$\begin{array}{l}\text { responsAbility Global } \\
\text { Microfinance Fund }\end{array}$} & EUR & 0.3319 & -0.0524 & -0.1695 & 0.0251 & -0.0885 \\
\hline & USD & 0.5446 & -0.0802 & -0.2530 & 0.0698 & -0.0702 \\
\hline & $\mathrm{CHF}$ & 0.0118 & -0.0017 & -0.0056 & 0.0011 & -0.0022 \\
\hline $\begin{array}{l}\text { responsAbility } \\
\text { Microfinance Leaders } \\
\text { Fund }\end{array}$ & USD & 0.5982 & -0.0733 & -0.1229 & 0.1669 & -0.0433 \\
\hline \multirow{3}{*}{$\begin{array}{l}\text { Dual Return - Vision } \\
\text { Microfinance Fund }\end{array}$} & USD / Class P & 0.2708 & 0.0827 & 0.1283 & 0.0324 & 0.0757 \\
\hline & EUR / Class P & 0.1171 & -0.0096 & -0.0306 & -0.0211 & -0.0136 \\
\hline & CHF / Class P & -0.3272 & 0.0429 & 0.1147 & 0.1376 & 0.0591 \\
\hline \multirow{3}{*}{$\begin{array}{l}\text { Dexia Micro-Credit } \\
\text { Fund - BlueOrchard } \\
\text { Debt Sub-Fund }\end{array}$} & EUR & 0.5961 & -0.0860 & -0.3257 & 0.0846 & -0.1622 \\
\hline & $\mathrm{CHF}$ & -0.0017 & 0.0003 & 0.0017 & -0.0002 & 0.0020 \\
\hline & USD & 0.9481 & -0.4757 & 1.3320 & 0.0361 & 0.2058 \\
\hline $\begin{array}{l}\text { Edmond de Rothschild } \\
\text { - Saint-Honore } \\
\text { Microfinance }\end{array}$ & EUR & -0.0849 & 0.0107 & 0.0314 & 0.0124 & 0.0114 \\
\hline \multicolumn{2}{|l|}{ Mean of selected MIVs } & 0.2731 & -0.0584 & 0.0637 & 0.0495 & -0.0024 \\
\hline \multicolumn{7}{|l|}{ Benchmark indices } \\
\hline \multicolumn{2}{|l|}{ MSCI World Index } & -0.2376 & -0.0125 & & & \\
\hline \multicolumn{2}{|c|}{$\begin{array}{l}\text { MSCI Emerging Markets Diversified } \\
\text { Financials Index }\end{array}$} & -0.0632 & & -0.0067 & & \\
\hline \multicolumn{2}{|l|}{ iBoxx USD Overall Index } & 0.1093 & & & 0.0015 & \\
\hline \multicolumn{2}{|c|}{$\begin{array}{l}\text { J.P. Morgan Emerging Bond Index } \\
(\mathrm{EMBI}+)\end{array}$} & 0.0028 & & & & 0.0001 \\
\hline
\end{tabular}

Source: own calculations on data from Bloomberg 
The key role of risk and return measurements and indicators in the business evaluation is emphasized by Voronova (2008) and Jarrett and Schilling (2008). The risk and performance measures which we used in our study to evaluate the desirability of investment into microfinance are obviously only one of many possible approaches to this problem. All our measures use a standard single-criterion evaluation approach a opposed to multiple- objective approach used for example by Brauers et al. (2008), Ginevičius and Podvezko (2008a, b, 2009) and Ginevičius et al. (2008) in a number of interesting applications to banking, finance and business. The problem of investment portfolio management we consider in this article is quite distinct one from the problems faced in evaluation of commercial bank loan portfolio which is considered by Mačerinskienè and Ivaškevičiūtè (2008). It is also different from the problems of credit risk management in commercial companies which is described by Jasienè and Laurinavičius (2009). In our paper we take the form of the contract as given as opposed to a sizeable literature dealing with optimal contracting, which is reviewed by Janda $(2006,2007)$.

Our results about portfolio performance of microfinance funds are quite important for the investment decisions of international investors, who are the most likely to invest into these funds. Our findings therefore contribute to extensive literature about the role of foreign investments (and investments in general) in the economic development of emerging markets. For a relevant overview of this investment related literature see recent papers by Tvaronavičienė et al. (2008), Tvaronavičius and Tvaronavičienè (2008) and Tvaronaviciene et al. (2009) which concentrates on international comparison of development processes.

\section{Conclusions}

This case study of eleven microfinance investment funds and their sub-funds pointed to some interesting original results both in terms of risk related to investment in microfinance as well as returns offered.

We found out that the extent of total risk, which is especially useful to asses if microfinance funds are held alone, reached very low levels (measured by the standard deviation of historical returns) comparable to the properties of the risk-free asset. The total risk recorded surely much lower levels than one would expect from an investment where underlying assets are debt or equity stakes in institutions that lend money to low-income and poor customers without the right on collateral. On the other hand, investors that wish to hold shares in microfinance investment funds as a part of broad portfolio of assets shall focus on the symmetric (non-diversifiable) risk of MIVs that was estimated from the linear regression of risk-free rate adjusted monthly returns of microfinance funds in the sample against the premium offered by the market (equity and bond). It revealed that the development of MIVs' returns only slightly tracks with the movement of the market which was demonstrated by low values of R-squared as well as close-to-zero estimates of the regression parameter beta with respect to all four indices (also after having accounted for the break in the development of the estimated parameter beta related to the benchmark equity index). 
Based on the historical data, we conclude that there is no positive correlation between broader market and MIVs. The symmetric (market) risk of microfinance investment funds' shares is therefore close to zero, which implies that an addition of microfinance assets to a broader portfolio may help to reduce the overall risk of a portfolio and should be attractive from the portfolio diversification point of view. From this point of view, our results are in line with works of Galema et al. (2008) as well as Kraus and Walter (2008) that did not tackle the microfinance investment funds but analyzed broader financial data of MFIs themselves.

With regard to examined funds' performance results we have seen that studied MIVs had provided moderate but stable returns over the study period no matter the sentiment on global financial markets. With respect to the total risk-adjusted returns, recorded positive values of the Sharpe ratio for most funds (which were not derived from the regression, however) indicate that investors had been well compensated for the underlying risk when holding other than risk-free assets (here the 4-week U.S. Treasury Bill). With respect to this matter, only fixed income investment could countervail MIVs in the sample even thought they reached lower (but still positive) Sharpe ratio values, therefore lower risk premium for an investor.

As our task was also to confirm whether the performance of studied microfinance funds surpasses returns generated by benchmark indices we focused on the Jensen's alpha referring to funds' excess returns. At the first sight, almost all MIVs in average outperformed given equity and bond market indices (when the whole period of examination is taken into account). Nevertheless, detailed study of two time intervals denoting firstly growing and then decreasing world equity markets revealed significant changes in the alpha measure of funds' excess return. With respect to this fact, we can not rely on alpha estimates from the first overall model that pointed to positive and on average rather important excess returns of MIVs over benchmark indices. Therefore, we conclude that microfinance investment funds in average do not reach any added returns above those returns that compensate an investor for the symmetric risk measured by the beta.

To sum up, in terms of microfinance total risk the analysis suggests that examined funds have recorded lower total risk than global stocks and bonds (measured by four benchmark indices) with moderate but stable returns. Nevertheless, they bring along a new third dimension - important social returns. In addition, the analysis revealed that investment in microfinance investment funds that focus especially on debt instruments represents an attractive opportunity for the portfolio diversification as this asset class does not show any positive correlation with global or emerging capital markets.

At the same time, it provides adequate risk-adjusted returns and may be therefore attractive not only for investors with a particular interest in the social responsible aspect of this investment opportunity. For that reason, we may expect greater development of the sector of microfinance investment vehicles and an increase in the flow of funds to microfinance institutions in developing countries. Consequently, we may hope in expanded access of low-income customers to financial resources and improvement of their economic conditions. 
It needs to be noted that our conclusions represent only a case study-based evidence on risk and performance characteristics of microfinance investment funds or investment vehicles in the broader sense. The sample includes only microfinance investment vehicles that are organized in the form of mutual funds (SICAV or FCP) that are all characterized by a high level of commercialization. They are either sponsored or their assets are managed by some important European banks (Dexia or Credit Suisse in case of both responsAbility funds), their performance data as well as monthly briefing reports are publicly available and are regularly updated. Put in another words, it is evident that funds that were included in the sample are not representative of the whole microfinance investment vehicles universe, which is in reality more heterogeneous. Nevertheless, since we are interested in the flow of funds from "north to south", i.e. from developed capital markets to the new emerging asset class of microfinance, we may expect that those investors will, in the first place, eventually invest in the most developed and stable investment vehicles.

Despite of conclusions that we draw from the case study, current global recession that was triggered by the crisis in the financial sector may bring some restrains to further development of this investment class (Dokulilova et al. 2009). Although analyzed time series covered both periods of the business cycle in the global economy, the recession is not over yet even in the most developed economies. From whence it follows to ask whether the microfinance will remain immune from the global financial crisis or whether the global financial crisis and recession of such extent will not have repercussions on the least developed economies where MFIs act only later on during 2009 and 2010.

The structural break in our data due to the recent credit crisis is an important limitation of the generality of our results. We tested for the stability of regression coefficient with respect to splitting the sample into pre-crisis and crisis period. We discovered that for some investment funds the structural break is clear and the regression coeficients are significantly different in both periods. For some funds we did not confirm the hypothesis of structural break.

The impacts of financial crisis could have a dual character as we may witness worsened rates of repayment reflecting greater depression in developing countries. Secondly, more MFIs may lack necessary sources for refinancing due to an increased global negative sentiment. Then increased costs of funding, tighter net interest margins together with possible augmented instability of the exchange rate terms and increased cost of hedging - that all could have negative impacts on financial results of microfinance institutions and therefore on the share value of specialized microfinance investment funds. Therefore, it seems to be too early to sum up that the microfinance segment in terms of its returns was not touched by global affairs and this topic may be a subject of further research.

\section{Acknowledgements}

The work on this paper was supported by the Czech Science Foundation, grants 402/09/0380, 403/10/1235 and by the research project MSM0021620841. The successful accomplishment of this project was facilitated by a generous support from University of Economics, Prague for a sabbatical leave of the corresponding author to the University of California, Berkeley. 


\section{References}

Armendáriz de Aghion, B.; Morduch, J. 2005. The Economics of Microfinance. Cambridge, MA: MIT Press.

Bassem, B. S. 2009. Governance and performance of microfinance institutions in Mediterranean countries, Journal of Business Economics and Management 10(1): 31-43.

doi:10.3846/1611-1699.2009.10.31-43

Bauer, M.; Chytilová, J.; Morduch, J. 2008. Behavioral Foundations of Microcredit: Experimental and Survey, Evidence From Rural India. Prague: Charles University in Prague, Faculty of Social Sciences, Institute of Economic Studies.

Brauers, W. K. M.; Zavadskas, E. K.; Turskis, Z.; Vilutiene, T. 2008. Multi-objective contractor's ranking by applying the MOORA method, Journal of Business Economics and Management 9(4): 245-255. doi:10.3846/1611-1699.2008.9.245-255

Cassar, A.; Wydick, B. 2008. [Online]. Does social capital matter? Evidence from a five-country group lending experiment [Cited 18 July 2010]. Available from Internet: $<$ http://bellarmine2.lmu.edu/ economics/papers/Cassar\%20and\%20Wydick\%20JEEA.pdf>.

Cull, R.; Demirgüç-Kunt, A.; Morduch, J. 2008. [Online]. Microfinance meets the market. World Bank Policy Research Working Paper No. 4630 [Cited 25 April 2009]. Available from Internet: <http://econ. worldbank.org>.

Dokulilova, L.; Janda, K.; Zetek, P. 2009. [Online]. Sustainability of Microfinance Institutions in Financial Crisis. MPRA Paper 17696. [Cited 18 July 2010]. Available from Internet: <http://mpra. ub.uni-muenchen.de/17696/>.

de Sousa-Shields, M.; Frankiewicz, C. 2004. [Online]. Financing Microfinance Institutions: The Context for Transitions to Private Capital. USAID microREPORT No. 8. [Cited 20 February 2009].Available from Internet: $<$ http://www.esglobal.com/pdf/Financing\%20Microfinance\%20Institutions.pdf $>$.

Dieckmann, R. 2007. [Online]. Microfinance: An emerging investment opportunity. Uniting social investment and financial returns. Deutsche Bank Research. December 2007. [Cited 20 February 2009]. Available from Internet: <http://www.dbresearch.com>.

Forster, S.; Reille, X. 2008. [Online]. Foreign capital investment in microfinance: balancing social and financial returns. Washington: CGAP, Focus Note No. 44, February 2008. [Cited 18 July 2010]. Available from Internet: <http://www.cgap.org/gm/document-1.9.2584/FN44.pdf> .

Galema, R.; Lensink, R.; Spierdijk, L. 2008. [Online]. International diversification and microfinance. Netherlands: University of Groningen, working paper series. [Cited 25 April 2009]. Available from Internet: <http://ssrn.com/abstract=1286769>.

Giné, X.; Jakiela, P.; Karlan, D. S.; Morduch, J. 2006. Microfinance Games. Yale University Economic Growth Center Discussion Paper No. 936. [Cited 18 July 2010]. Available from Internet: <http://ssrn. com/abstract $=912301>$.

Ginevičius, R.; Podvezko, V. 2009. Evaluating the changes in economic and social development of Lithuanian counties by multiple criteria methods, Technological and Economic Development of Economy 15(3): 418-436. doi:10.3846/1392-8619.2009.15.418-436

Ginevičius, R.; Podvezko, V. 2008a. Multicriteria graphical-analytical evaluation of the financial state of construction enterprises, Technological and Economic Development of Economy 14(4): 452-461. doi:10.3846/1392-8619.2008.14.452-461

Ginevičius, R.; Podvezko, V. 2008b. Multicriteria evaluation of Lithuanian banks from the perspective of their reliability for clients, Journal of Business Economics and Management 9(4): 257-267. doi:10.3846/1611-1699.2008.9.257-267

Ginevičius, R.; Podvezko, V.; Bruzgè, S. 2008. Evaluating the effect of state aid to business by multicriteria methods, Journal of Business Economics and Management 9(3): 167-180.

doi:10.3846/1611-1699.2008.9.167-180 
Gonzalez, A. 2007. [Online]. Resilience of Microfinance Institutions to National Macroeconomic Events: An Econometric Analysis of MFI Asset Quality. Microfinance Information Exchange, Inc., Discussion Paper No. 1, July 2007. [Cited 11 May 2009]. Available from Internet: <http://mpra.ub.unimuenchen.de/4317>.

Goodman, P. 2004. [Online]. Microfinance Investment Funds: Objectives, Players, Potential. Kreditanstalt fur Wiederaufbau (KfW), November 2004. [Cited 11 May 2009]. Available from Internet: <http:// www.mfc.org.pl/images/pliki/17.pdf>.

Hubner, G. 2005. [Online]. The Generalized Treynor Ratio, Review of Finance 9: 415-435. [Cited 11 May 2009]. Available from Internet: $<\mathrm{http}: / /$ ssrn.com/abstract=780245>.

Ivatury, G.; Abrams, J. 2005. [Online]. The Market for Foreign Investment in Microfinance: Opportunities and Challenges. Washington: CGAP, Focus Note No. 30, August 2005. [Cited 11 May 2009]. Available from Internet: <http://www.cgap.org/p/site/c/template.rc/1.9.2574>.

Ivatury, G.; Reille, X. 2004. Foreign Investment in Microfinance: Debt and Equity from Quasi-Commercial Investors. Washington: CGAP, Focus Note No. 25, January 2004. [Cited 11 May 2009]. Available from Internet: <http://www.cgap.org/p/site/c/template.rc/1.9.2569>.

Janda, K. 2007. Optimal Debt Contracts in Emerging Markets with Multiple Investors, Prague Economic Papers 2(16): 115-129 .

Janda, K. 2006. [Online]. Lender and Borrower as Principal and Agent. Working Paper No.24/2006, Institute of Economic Studies, Charles University. [Cited 18 July 2010]. Available from Internet: $<$ http://ies.fsv.cuni.cz/default/file/download/id/8852>.

Janda, K. 1994. Modelovani rizika akcioveho portfolia [Modelling Risks of Share Portfolio], Finance a uver 44(9): 463-72 (in Czech).

Jarrett, J. E.; Schilling, J. 2008. Daily variation and predicting stock market returns for the Frankfurter Borse (Stock Market), Journal of Business Economics and Management 9(3): 189-198.

doi:10.3846/1611-1699.2008.9.189-198

Jasienè, M.; Laurinavičius, A. 2009. Problems of Credit Risk Management in Companies and Means of their Solution, Business: Theory and Practice 10(1): 15-29. doi:10.3846/1648-0627.2009.10.15-29

Krauss, N. A.; Walter, I. 2008. [Online]. Can microfinance reduce portfolio volatility? NYU Working Paper No. FIN-06-034. [Cited 25 April 2009]. Available from Internet: <http://ssrn.com/abstract $=1300771>$.

Mačerinskienè, I.; Ivaškevičiūtè, L. 2008. The evaluation model of a commercial bank loan portfolio, Journal of Business Economics and Management 9(4): 269-277.

doi:10.3846/1611-1699.2008.9.269-277

Meehan, J. 2004. [Online]. Tapping the financial markets for microfinance: grameen foundation USA's promotion of this emerging trend. Grameen Foundation USA Working Paper Series, October 2004. [Cited 11 May 2009]. Available from Internet: <http://www.haas.berkeley.edu/HaasGlobal/docs/gfusacapitalmarketswp1004.pdf>.

O’Donohue, N.; Rozeira de Mariz, F.; Littlefied, E.; Reille, X.; Kneiding C. 2009. [Online]. Shedding light on microfinance equity valuation: past and present, CGAP and J. P. Morgan, No. 14 February 2009. [Cited 18 July 2010]. Available from Internet: <http://www.cgap.org/p/site/c/template.rc/1.9.9021>.

Reille, X.; Sananikone, O. 2007. [Online]. Microfinance investment vehicles, Washington: CGAP, Brief, April 2007. [Cited 11 May 2009]. Available from Internet: <http://www.cgap.org/p/site/c/template.rc/1.9.2734>.

Tvaronavičienė, M.; Grybaite, V.; Korsakienè, R. 2008. Foreign capital destinations: Baltic States versus India, Journal of Business Economics and Management 9(3): 227-234.

doi:10.3846/1611-1699.2008.9.227-234

Tvaronavičienė, M.; Grybaitè, V.; Tvaronavičienė, A. 2009. If institutional performance matters: development comparisons of Lithuania, Latvia and Estonia, Journal of Business Economics and Management 10(3): 271-278. doi:10.3846/1611-1699.2009.10.271-278 
Tvaronavičius, V.; Tvaronavičienė, M. 2008. Role of fixed investments in economic growth of country: Lithuania in European context, Journal of Business Economics and Management 9(1): 57-64. doi:10.3846/1611-1699.2008.9.57-64

Voronova, I. 2008. Methods of analysis and estimation of risks at the enterprises of non-financial sphere of Latvia, Journal of Business Economics and Management 9(4): 319-326.

doi:10.3846/1611-1699.2008.9.319-326

\section{INVESTAVIMAS I MIKROFINANSUS}

\section{K. Janda, B. Svárovská}

Santrauka

Šiame straipsnyje nagrinejjamos investicijos į investicinius mikrofinansų fondus. Nagrinejjami fondai yra žemesnès bendrosios rizikos nei pasaulio akcijos ir obligacijos (apskaičiuotos pagal keturis atskaitos rodiklius) su vidutiniška, bet stabilia grąža. Analizė parodè, kad investavimas į investicinius mikrofinansų fondus, ypač ị susijusius su ịsiskolinimo priemonèmis, yra patraukli galimybè verslo portfelio diversifikacijai, nes ši turto kategorija nerodo jokios teigiamos koreliacijos su pasaulio ar naujomis kapitalo rinkomis. Tuo pačiu metu tai teikia adekvačią grąžą pagal riziką ir todèl gali būti patrauklūs ne tik investuotojams, turintiems tam tikrų interesų.

Reikšminiai žodžiai: mikrofinansai, investavimas, fondai, rizika, grąža, regresija.

Karel JANDA. Professor at Department of Banking and Insurance, Faculty of Finance and Accounting, University of Economics, Prague and at Department of Microeconomics and Mathematical Methods, Institute of Economic Studies, Faculty of Social Sciences, Charles University, Prague. He is Affiliate Fellow at CERGE-EI. He is a holder of RWE-Trangas Group chair in Economics at Institute of Economic Studies, Charles University. He works in the area of microeconomics of banking.

Barbora SVÁROVSKÁ. M.A. student in Economics of International Trade and European Integration organized as a European Joint Studies Program with University of Antwerp as the coordinating institution. At the same time, she pursues her Masters studies in Finance, Financial Markets and Banking at the Institute of Economic Studies of Charles University in Prague. She holds a Bachelors degree in Economic Theories from the same institute. Her research interests are in the area of finance theory applied to microfinance. 